\title{
Late Pleistocene fans and terraces in the Majes valley, southern Peru, and their relation to climatic variations
}

\author{
Damian Steffen • Fritz Schlunegger • \\ Frank Preusser
}

Received: 19 November 2008/Accepted: 10 October 2009/Published online: 15 November 2009

(C) Springer-Verlag 2009

\begin{abstract}
This study investigates the connection between sediment aggradation, erosion and climate in a desert environment of the Majes valley, southern Peru. Luminescence dating of terraces and fans shows that sediment aggradation correlates with wet time intervals on the Altiplano, suggesting a climatic influence on the aggradation-degradation cycles. Major periods of aggradation occurred between $\sim 110-100, \sim 60-50$ and 12-8 ka. More precipitation in the Majes catchment resulted in increased erosion and transportation of sediment from the hillslopes into the trunk river. As a result, the sediment loads exceeded the transport capacity of the Majes River and aggradation started in the lower reaches where the river gradient is less. Depletion of the hillslope sediment reservoirs caused a relative increase in the capacity of the trunk river to entrain and transport sediment, resulting in erosion of the previously deposited sediment. Consequently, although climate change may initiate a phase of sediment accumulation, degradation can be triggered by an autocyclic negative feedback and does not have to be driven by climatic change.
\end{abstract}

Keywords Alluvial fan - Terrace $\cdot$ Luminescence dating . Peru $\cdot$ Paleoclimate

\section{Introduction and motivation}

The response of geomorphic systems to climate change has been a challenging research field in fluvial geomorphology.

D. Steffen $(\bowtie) \cdot$ F. Schlunegger · F. Preusser

Institute of Geological Sciences, Universität Bern,

Bern, Switzerland

e-mail: steffen@geo.unibe.ch
Records of change are preserved in stratigraphic archives, and successful reconstructions of response require a correct interpretation of these archives, which, in turn, crucially depends on the chronological framework. In their review paper on fluvial response to climate and sea-level changes, Blum and Törnqvist (2000) conclude that the majority of research has focused on the past $20 \mathrm{ka}$ at most because of a lack of adequate tools to assess the age of older deposits. Therefore, very little is known about how sediment transfer in a drainage network changes with external forcing, in general, and climate change, in particular, which operate at longer time scales. Luminescence dating is an important tool for studies over longer time spans, because the material required (i.e. quartz and feldspar minerals present as fine- to medium-grained sand) is abundant in almost all sedimentary environments, which is not always the case with organic matter necessary for radiocarbon dating. Furthermore, the age range of luminescence dating is in the order of several hundred thousand years, depending on the luminescence properties of the sample (e.g. Wallinga 2002).

The western escarpment of the Andes in southern Peru has proven to be an ideal region to study the response of the sediment transfer system to climate perturbations because Late Pleistocene cut-and-fill terraces that are recorders of change are abundant (e.g. Steffen et al. 2009a), and the aridity allows for the preservation of these archives. Previous studies have been limited to the Peruvian coast and, with few exceptions, to late Holocene time scales (e.g. Fontugne et al. 1999; Keefer et al. 2003; Magilligan and Goldstein 2001; Magilligan et al. 2008; Sandweiss 2003; Wells 1990). Most of this research relates sediment deposition to warm El Niño-Southern Oscillation (ENSO) events (El Niño), although assignments of sedimentary deposits to high magnitude precipitation events have been 
challenged (Ortlieb and Vargas 2003; Vargas et al. 2006). Farabaugh and Rigsby (2005) and Rigsby et al. (2003) studied fluvial terraces on the Altiplano linking climate variabilities (especially lake-level changes) with periods of sediment deposition and terrace formation. Time intervals of landsliding and sediment aggradation in Andean valleys have also been correlated with periods of increased precipitation, as well as downcutting with periods of decreased precipitation (Trauth et al. 2003). These studies suggest that major changes in sediment flux occur during periods of climatic transitions, in general, and possibly in relation to a modification of the magnitude-frequency distribution of precipitation rates, in particular.

In a recent work that focused on terrace systems in the Pisco valley, southern Peru, Steffen et al. (2009a) proposed that terrace and fan formation occurs where hillslopes and trunk streams respond differently to climate variability, and that the resulting non-linear variations in sediment discharge may be responsible for the temporary storage of sediment on valley floors. In particular, these authors found that an increase in precipitation rates results in an increase in sediment discharge from the hillslopes to the channel network, which in turn may exceed the sediment transport capacity of the receiving trunk stream. As hillslopes become depleted, the relative capacity of trunk streams to transport and entrain sediment increases, and rivers incise into previously deposited sediment. This paper complements and expands the investigations of the Pisco valley to a larger scale by analysing fans, terrace systems and talus deposits in the Majes valley near Arequipa, southern Peru. Similar to the situation at Pisco, these deposits possibly bear information about the response of the drainage network to climate change. Accordingly, the sedimentary fabric and the petrofacies have been studied in detail and fitted to a precise temporal framework provided by infrared stimulated luminescence (IRSL) ages.

\section{Regional settings}

Geographic and geomorphic setting and chronology of valley formation

The drainage basin of the Majes River is located in southern Peru and debouches into the Pacific at $16.6^{\circ} \mathrm{S}$ and $72.7^{\circ} \mathrm{W}$ (Fig. 1). It has an area of about $17,400 \mathrm{~km}^{2}$, and the longest flow path measures approximately $380 \mathrm{~km}$. Note that although the trunk river is called the 'Colca River' in the headwaters, the 'Majes River' in the middle section, and the 'Camaná River' at the coast by the local community, we use the term 'Majes River' for simplicity because our study mainly covers the middle section. During the past decades, peak monthly discharges of the Majes River have been between 300 and $450 \mathrm{~m}^{3} / \mathrm{s}$, and in extreme cases $2,000 \mathrm{~m}^{3} / \mathrm{s}$, while magnitudes of normal water discharge are about $30-40 \mathrm{~m}^{3} / \mathrm{s}$, especially during austral summer (Servicio Nacional de Meteorología e Hidrológica del Perú). The highest point of the drainage basin is the volcano Nevado Coropuna with an elevation of about 6,400 masl. This volcano has been dormant since at least the Late Glacial (Thouret et al. 2002) and is covered by glaciers.

The catchment of the Majes River can be roughly subdivided into two geomorphic domains that are separated by
Fig. 1 Hill-shaded catchment of the Majes River derived from SRTM 90 m data. Figure on the lower right shows a zoom of the investigated reach with sample locations. The two insets show the location of the Majes drainage basin within South America and the river profile along the longest flow path of the catchment

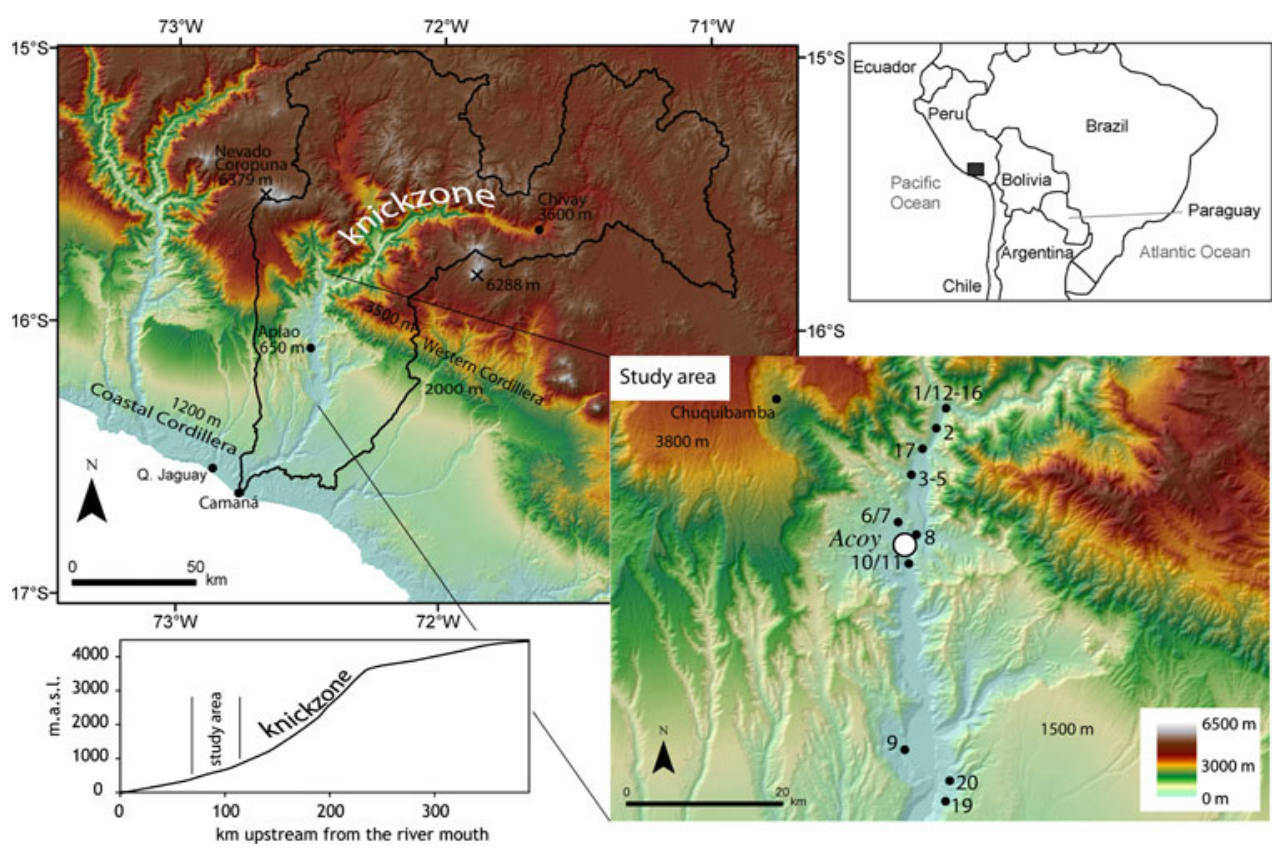


a pronounced knickzone in the longitudinal stream profile (Fig. 1). The unit above the knickzone is characterized by a relatively smooth topography with gentle slopes (Figs. 2a, 3), and terrace (Fig. 2a) and fan deposits are widespread. At the knickzone, the river exposes bedrock, and channel gradients increase from values between 1 and $2 \%$ to greater than $4 \%$. Also in the region of the knickzone, close to the trunk river, hillslope angles are up to $70^{\circ}$ (Fig. 3) and thus exceed threshold conditions for failure. The region surrounding the knickzone is also one of the deepest canyons on earth (Colca canyon) with a local relief of more than 3,000 m (Fig. 2b). This high relief is presumably the result of headward erosion of the Majes River that is attributed to a Late Miocene phase of enhanced surface uplift, during which the Central Andean plateau rose between 1,500 and 2,400 m (e.g. Schildgen et al. 2007; Schlunegger et al. 2006; Garzione et al. 2008). The segment surrounding the knickzone has probably also been an area of enhanced sediment production, in part due to mechanical failure of oversteepened hillslopes in response to bedrock incision of the Majes River. The study area lies downstream of the knickzone where terraces, fans and talus deposits have been analysed. Note, however, that terraces are rare and only occur in some places, whereas fans are much more widespread. Here, the river gradient is $\sim 1.06 \%$ and the river belt is made up of braided channels that are laterally bordered by longitudinal gravel bars (Fig. 2c). The hillslopes are covered by a metre-thick mantle of weathered bedrock and generally dip at $<30^{\circ}$ (Fig. 3). Also beneath the knickzone, the valley width increases from a few metres to $100 \mathrm{~m}$ near the lower end of the knickzone, to $500 \mathrm{~m}$ some $5 \mathrm{~km}$ farther downstream, and finally to 2 $3 \mathrm{~km}$ after an additional $15 \mathrm{~km}$. Interestingly, the occurrence of terraces is limited to the uppermost $30 \mathrm{~km}$ of the segment beneath the knickzone. In the lowermost reaches, the hillslopes and tributaries are decoupled from the trunk river, with a transition formed by a bedrock step.

Thouret et al. (2007) suggested that formation of the Majes valley and downcutting to the present valley floor were almost completed between 9 and $3.8 \mathrm{Ma}$. Incision to the modern base level was followed by valley refill of pyroclastic flows until $\sim 1.36 \mathrm{Ma}$. The same authors also suggest that since then, re-incision into these Pliocene nonwelded pyroclastic deposits has occurred in three phases, with the latest of these phases occurring between 530 and $200 \mathrm{ka}$. Several breaks in the present longitudinal profiles are between 30 and $80 \mathrm{~m}$ high and indicate that incision has not been in equilibrium for much of the younger canyon history (Thouret et al. 2007). This is due to lava flow or mass failure events that resulted in accumulation of sediment on the valley floor at different times and various locations (e.g. Korup 2006, for the situation in the Alps).

\section{Geologic setting}

The bedrock of the Majes drainage basin is dominated by Tertiary and Quaternary volcanic rocks (mainly andesitic and dacitic tuffs, and ignimbrites) originating from a phase
Fig. 2 a Terraces in the upper part of the Majes drainage basin, above the knickzone. $\mathbf{b}$ View of the deeply incised Colca canyon in the middle part of the Majes catchment, where the knickpoint is located. There, the hillslopes are steeper than in the upper and lower parts of the valley. c Lower part of the Majes valley with a large floodplain of the braided Majes River. No terraces are present in this part of the valley

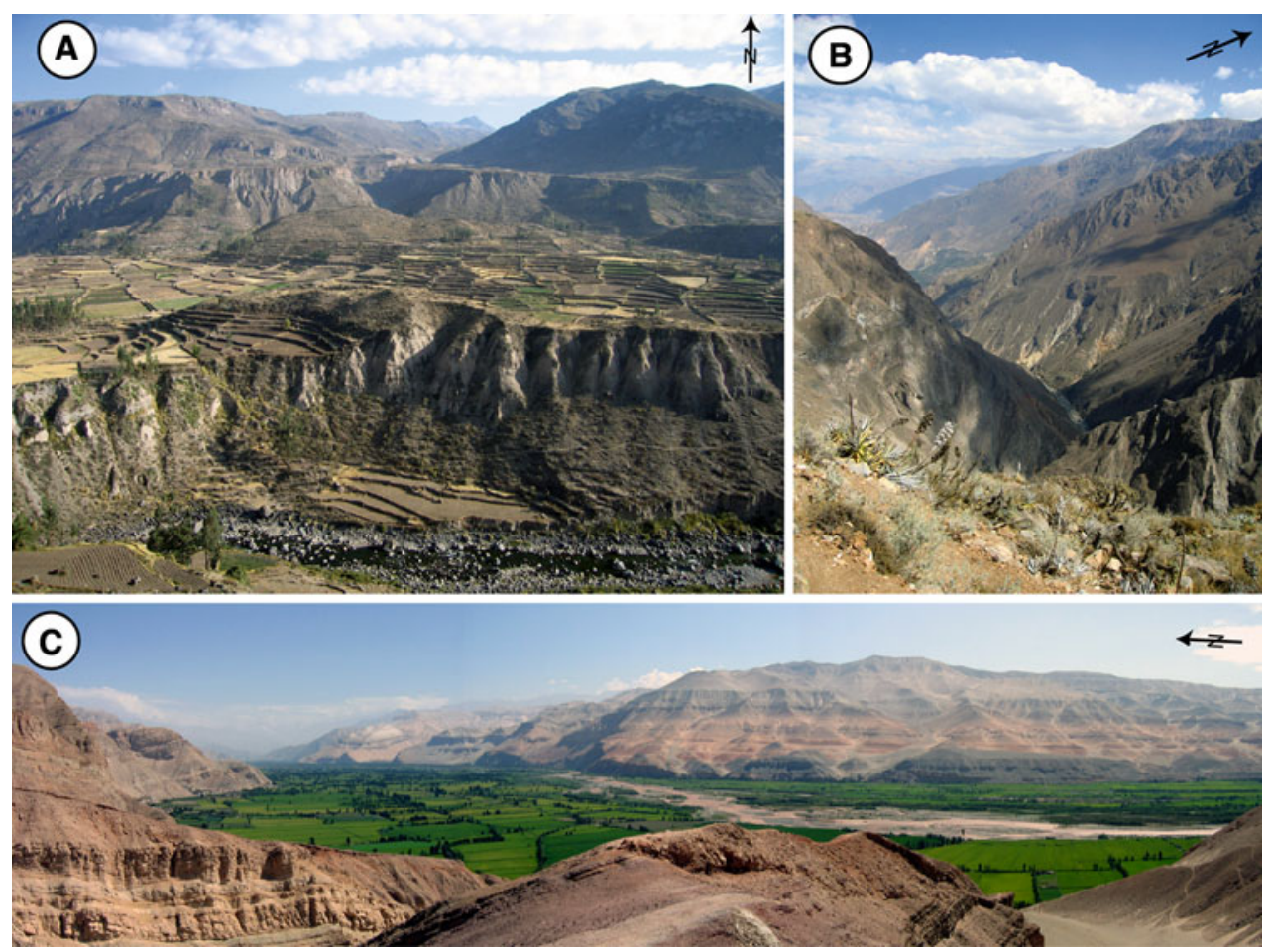




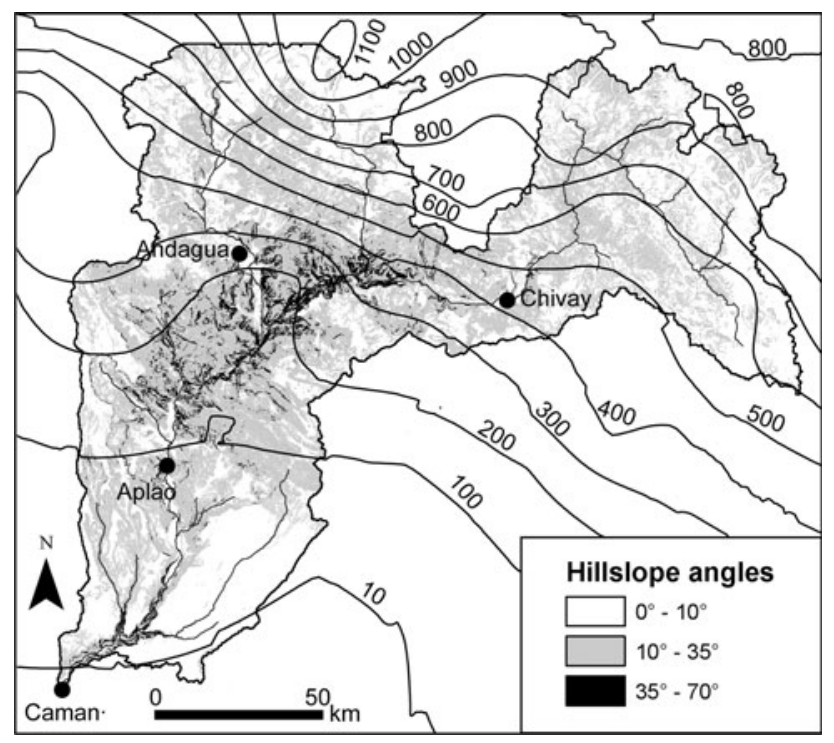

Fig. 3 Hillslope angle map of the Majes catchment overlain by the precipitation pattern. Precipitation data were compiled by Agrotecnologica Amazonica. The black lines show precipitation rates $(\mathrm{mm} /$ annum)

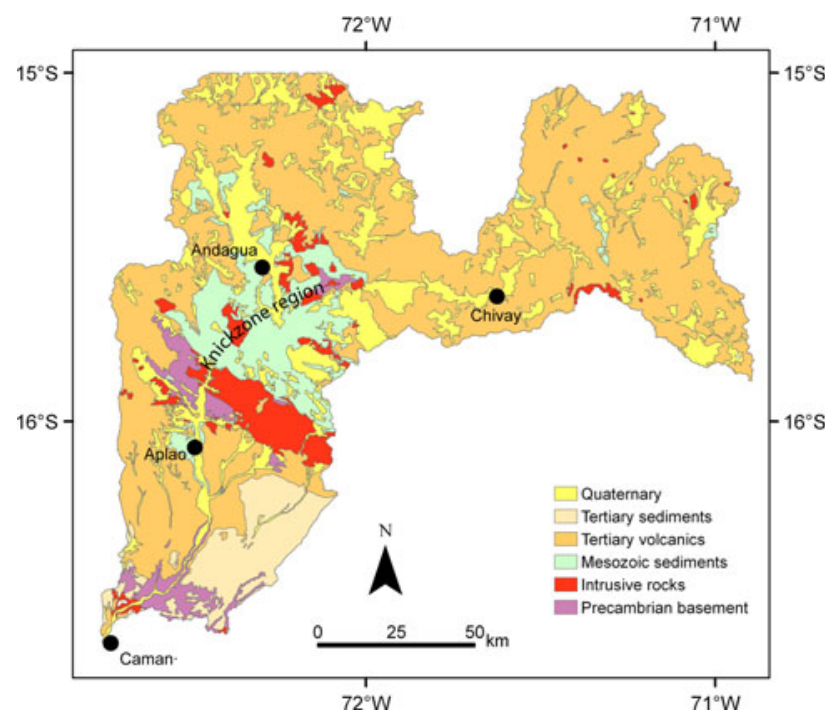

Fig. 4 Simplified geological map of the Majes drainage basin (compiled from 1:100000 geological maps from the Instituto Geológico Minero y Metalúrgico of Peru)

of major volcanic activity in the Andes (Vidal 1993). These volcanoclastic deposits rest with an angular unconformity on Mesozoic and Early Tertiary sedimentary rocks, which outcrop in the region surrounding the knickzone (Fig. 4). The sediments comprise alternating sandstones, marls and limestones of various thicknesses. The most important sedimentary unit is the Grupo Yura with an average thickness of about 2,500 m. Other formations have thicknesses of several hundreds of metres. These units were intruded by Late Cretaceous to Late Miocene plutonic rocks of various compositions (mainly diorites, but also tonalites, granites and granodiorites) that are part of the Coastal Batholith. Late Pleistocene and Holocene volcanic activity is widespread in southern Peru and also within the catchment of the Majes River (Thouret et al. 2002, 2007).

The Majes drainage basin is located near the leading edge of the Nazca Ridge that has been subducted beneath the South American plate since the Miocene (Hampel 2002). At Majes, uplift rates have been estimated to $\leq 0.2 \mathrm{~mm} / \mathrm{annum}$ and have been unaffected by oblique subduction of the ridge (Hsu 1992; Wipf et al. 2008). The seismic record of southern Peru shows that the area is still geodynamically active. The last major earthquake, with a magnitude of 8.2, occurred in June 2001 to the NW of the city of Camaná (epicentre at $16.20^{\circ} \mathrm{S}, 73.75^{\circ} \mathrm{W}$, with a focal depth of $38 \mathrm{~km}$; Instituto Geofísico de Peru) with large intensities also in the Majes valley [MedvedevSponheuer-Karnik scale (MSK) 6-7 from Camaná to Aplao, and MSK 5 for the rest of the catchment; Tavera et al. 2006].

\section{Climatic setting}

The climate of the western escarpment of Peru, in general, and that of the Majes drainage basin, in particular, has been influenced by two wind systems derived from the east (Atlantic) and the west (Pacific) (e.g. Garreaud et al. 2003; Houston and Hartley 2003). Along the Pacific coast, climate has been controlled by the Easter Island High and the Humboldt Current, both of which are responsible for the establishment of a persistent inversion thereby stabilizing the atmosphere and inhibiting convection (Woodman 1998). This results in an extremely dry climate along the southern Peruvian coast. This aridity is sometimes interrupted by El Niño events that are, especially in northern Peru and central Chile, characterized by strong precipitation events and major flooding (e.g. Ortlieb and Vargas 2003; Mettier et al. 2009). The influence of El Niño on the southern Peruvian coast is less clear (see discussion in Ortlieb and Vargas 2003). ENSOs not only affect the coastal area but also the Andes, where El Niño is normally associated with droughts and a rainfall deficit (Garreaud et al. 2003).

On the Altiplano and in the headwaters of the Majes River, the pattern of precipitation is closely related to the position of the subtropical jet stream and the intertropical convergence zone (ITCZ, Garreaud et al. 2003). When the position of the jet stream is on its southernmost edge (during austral summer, from December to February; Fig. 5), humidity from the tropical Amazon basin and the Atlantic is carried by the easterlies to the Altiplano (Garreaud et al. 2003). In contrast, during austral winter 


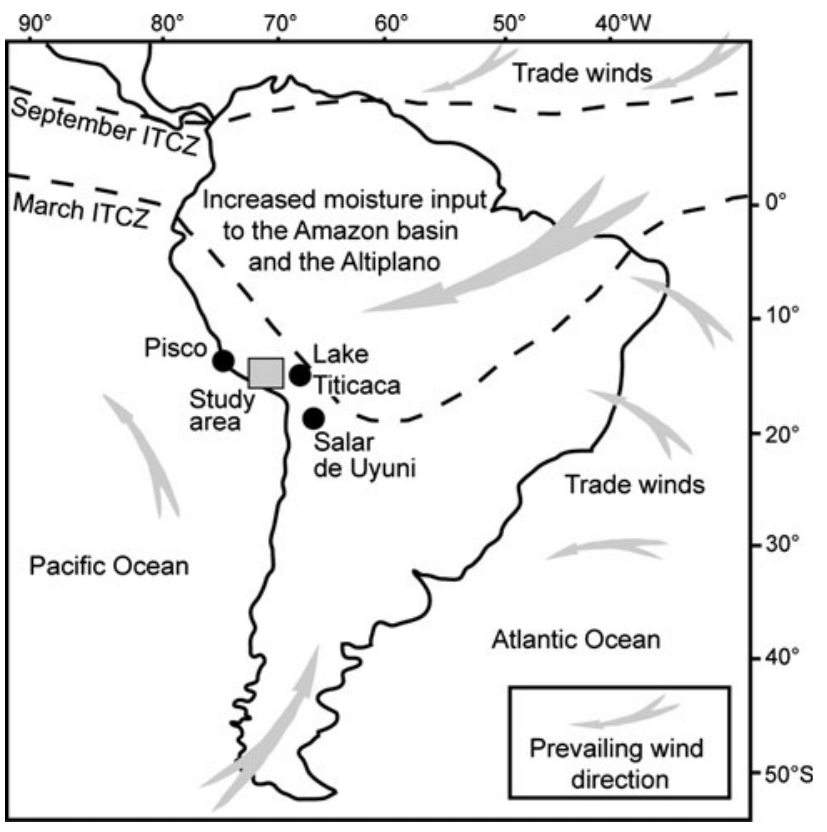

Fig. 5 Overview map of South America showing the prevailing wind directions and the position of the ITCZ in September and March (redrawn and modified after Wang et al. 2004). Black dots indicate the position of the paleolakes on the Altiplano and the city of Pisco (e.g. Fritz et al. 2004; Placzek et al. 2006). See text for more details

between March and November, the subtropical jet stream and the ITCZ are located farther north. The results are persistent dry westerly winds with almost no precipitation on the Altiplano. On orbital time scales, shifts in the earth's precession may enhance the contrast in heating between the northern and southern hemisphere leading to stronger upper-air easterlies and thus to more precipitation on the Altiplano. The timing of enhanced easterly winds (i.e. high summer insolation) is indeed synchronous with humid intervals on the Altiplano resulting in the Minchin and Tauca paleolakes between 47.8-36 and 26-14.9 ka according to radiocarbon and U/Th ages (Baker et al. 2001a, b; Fritz et al. 2004). Note that paleobotanic data suggest that increased precipitation leading to the formation of the Minchin paleolake started as early as $54.8 \mathrm{ka}$ (Chepstow-Lusty et al. 2005). The results of these authors reveal that these phases represent the longest lacustrine intervals during the past $170 \mathrm{ka}$. These statements were challenged by Placzek et al. (2006) who studied paleolake deposits on the Bolivian Altiplano, and reported ages of 120-98 ka for the sea-level highstand of the Ouki lake that was the second largest lake on the Altiplano. In addition, Placzek et al. (2006) suggest that Tauca was the deepest and largest paleolake that existed between 18.1 and 14.1 $\mathrm{ka}$. They also argued for the existence of a post-Tauca lake cycle (the Coipasa) between 13 and $11 \mathrm{ka}$. As already suggested by other researchers, Placzek and co-authors proposed that these paleolakes formed in response to increased moisture availability in the Amazon and enhanced transport of that moisture onto the Altiplano by strengthened trade winds. We anticipate here that stronger easterly winds also resulted in higher precipitation rates farther west, i.e. in the lower reaches of the Rio Majes drainage basin that is currently a desert.

At present, climate is arid along the coast and approximately $100 \mathrm{~km}$ farther inland ( $<250 \mathrm{~mm} / \mathrm{annum}$, Fig. 3), which covers about $40 \%$ of the Majes catchment. Farther upstream, $20 \%$ of the drainage basin lies within a semi-arid climate $(250-500 \mathrm{~mm} / \mathrm{annum})$. The headwaters of the catchment experience a temperate climate with an annual rainfall of 500-800 mm/annum (Fig. 3) that falls mainly in the austral summer and dry winters.

\section{Methods}

The processes leading to the formation of terraces, fans and talus deposits were reconstructed using sedimentological logs of representative sections. Source areas of the deposits were delineated based on the results of clast counts that include the determination of the petrography of about 200 gravels $>2 \mathrm{~cm}$ in diameter, collected from an area of $1 \mathrm{~m}^{2}$ at five sites (see Schlunegger et al. 1993 for more methodological details). The morphometric properties of the Majes valley and the source area (size of catchments, stream profiles, slope analysis) were extracted from SRTM 90 m data.

Organic material suitable for radiocarbon dating is very rare in the Majes valley, and only two sites with pieces of wood were found and dated. Preparation and dating of the organic mater was conducted at the radiocarbon lab at the Physical Institute of the University of Bern. Luminescence dating offers a suitable alternative as quartz and feldspar are abundant, and it covers an age range of several hundreds of years up to several $100 \mathrm{ka}$. Using luminescence dating, it is possible to determine the time of deposition of the sediment, i.e. the time when the deposits were buried by subsequent sedimentation (see review by Wallinga 2002). It has been demonstrated that the luminescence technique can yield precise chronologies for fluvial and alluvial sediments (e.g. Rodnight et al. 2006; Spencer and Robinson 2008; Steffen et al. 2009a).

Luminescence dating procedure

A total of 18 samples from sites below the knickzone were collected and processed for luminescence dating (Fig. 1), and were preferentially taken from well-sorted, finegrained sand sheets (minimum $30 \mathrm{~cm}$ thick). If possible, sites were sampled where multiple terrace levels are present. Further details regarding appropriate facies for 
luminescence dating on alluvial fans are given by Robinson et al. (2005).

The samples were processed according to Mejdahl (1985) using coarse grains of either $100-150$ or $150-$ $200 \mu \mathrm{m}$. Tests revealed that the luminescence behaviour of quartz minerals was characterized by unstable signal components and a very dim fast component, a situation that was also present for quartz grains in the Pisco valley (Steffen et al. 2009b). We therefore selected potassiumrich feldspar as a dosimeter, following the successful application of IRSL dating of terraces and fans in a similar sedimentary environment (Steffen et al. 2009a). IRSL was measured using a Risø DA-20 TL/OSL reader, fitted with an internal ${ }^{90} \mathrm{Sr} /{ }^{90} \mathrm{Y}$ beta source. Infrared LEDs $(870 \mathrm{~nm})$ with an intensity of $108 \mathrm{~mW} \mathrm{~cm}^{-2}$ were used to stimulate the feldspar, and the emitted photons were filtered through a combination of a Schott BG39 and an interference filter, resulting in a maximum peak at $410 \mathrm{~nm}$. This second filter effectively removes the thermally unstable emission waveband of 280-290 nm, which would be detected through a conventional U340 filter and may be responsible for significant age underestimation in feldspar (Krbetschek et al. 1997). The equivalent dose $\left(D_{\mathrm{e}}\right)$ of potassium-rich feldspar was measured using a modified single-aliquot regenerative dose (SAR) protocol (Murray and Wintle 2000) with a similar preheat temperature for regenerative doses as well as for test doses (either 230 or $250^{\circ} \mathrm{C}$ for $60 \mathrm{~s}$ ). Dose recovery and preheat plateau tests showed that the SAR protocol worked well.

Fluvial and alluvial sediment may not always be fully bleached at the time of deposition, and this is referred to as partial bleaching, which may result in age overestimation (Wallinga 2002). It is thus important to exclude incompletely bleached grains when analysing the true $D_{\mathrm{e}}$ distributions for each sample. Therefore, various statistical approaches were used to identify the true burial age. For all samples, $D_{\mathrm{e}}$ was calculated using the median, central age model (CAM), minimum age model and finite mixture model (FMM, Galbraith and Green 1990; Galbraith et al. 1999). Application of the appropriate model was done following a decision process for single aliquots similar to the one proposed by Arnold et al. (2007). This was modified by stipulating an overdispersion of $>15 \%$ where the CAM was then discarded. Following the suggestions by Rodnight et al. (2006), the FMM was used for all samples where the CAM was considered inappropriate. Where the lowest component in the FMM included less than $10 \%$ of the grains, this component was also disregarded and the next youngest component was used for the calculation of $D_{\text {e. }}$

Anomalous fading was monitored using delayed $L_{\mathrm{x}} / T_{\mathrm{x}}$ measurements with delay times of 2 days and $\sim 3$ months and preheating prior to storage (Auclair et al. 2003). These
Table 1 Results of the fading tests using delayed $L_{\mathrm{x}} / T_{\mathrm{x}}$ measurements

\begin{tabular}{|c|c|c|c|}
\hline Sample & 2 Days $^{a}$ & 78 (101) Days ${ }^{\mathrm{a}}$ & 101/2 Days ${ }^{b}$ \\
\hline MAJ1 & $0.94 \pm 0.03$ & $0.95 \pm 0.02$ & $1.01 \pm 0.03$ \\
\hline MAJ2 & $0.94 \pm 0.05$ & $0.94 \pm 0.04$ & $1.00 \pm 0.08$ \\
\hline MAJ3 & $0.96 \pm 0.05$ & $1.02 \pm 0.05$ & $1.07 \pm 0.06$ \\
\hline MAJ4 & $0.97 \pm 0.02$ & $0.97 \pm 0.03$ & $1.01 \pm 0.01$ \\
\hline MAJ5 & $0.97 \pm 0.02$ & $1.01 \pm 0.04$ & $1.03 \pm 0.02$ \\
\hline MAJ6 & $0.96 \pm 0.03$ & $0.96 \pm 0.04$ & $1.00 \pm 0.03$ \\
\hline MAJ7 & $0.94 \pm 0.05$ & $0.94 \pm 0.06$ & $1.00 \pm 0.07$ \\
\hline MAJ8 & $0.99 \pm 0.02$ & $0.99 \pm 0.03$ & $1.00 \pm 0.02$ \\
\hline MAJ9 & $0.90 \pm 0.15$ & $0.85 \pm 0.10$ & $0.95 \pm 0.07$ \\
\hline MAJ10 & $0.95 \pm 0.05$ & $1.00 \pm 0.04$ & $1.06 \pm 0.09$ \\
\hline MAJ11 & $0.92 \pm 0.04$ & $1.00 \pm 0.02$ & $1.10 \pm 0.03$ \\
\hline MAJ12 & $0.89 \pm 0.03$ & $0.98 \pm 0.04$ & $1.10 \pm 0.07$ \\
\hline MAJ14 & $0.89 \pm 0.03$ & $0.90 \pm 0.06$ & $1.01 \pm 0.07$ \\
\hline MAJ15 & $0.91 \pm 0.05$ & $0.95 \pm 0.03$ & $1.05 \pm 0.06$ \\
\hline MAJ16 & $0.96 \pm 0.03$ & $0.95 \pm 0.05$ & $1.00 \pm 0.04$ \\
\hline MAJ17 & $0.97 \pm 0.01$ & $1.00 \pm 0.03$ & $1.03 \pm 0.04$ \\
\hline MAJ19 & $0.88 \pm 0.02$ & $0.97 \pm 0.06$ & $1.10 \pm 0.06$ \\
\hline MAJ20 & $0.87 \pm 0.04$ & $0.90 \pm 0.08$ & $1.03 \pm 0.11$ \\
\hline Average & $0.93 \pm 0.03$ & $0.96 \pm 0.04$ & $1.03 \pm 0.04$ \\
\hline
\end{tabular}

The samples were bleached, irradiated, preheated and then stored for a specific time. The ratio of the remaining signal compared to a 'direct' measurement is shown as well as the ratio of the long to short storage time to identify any fading over longer storage times

${ }^{\text {a }}$ Ratio of the signal measured after a storage time at room temperature compared to 'standard' delays as in the SAR protocol (approximately $7 \mathrm{~h}$ between irradiation and measurement)

${ }^{\mathrm{b}}$ Ratio of 101 to 2 days storage time

measurements show that the signal in most of the samples from the Majes valley decreases by about $5 \%$ compared to measurements without delay (average fading ratio after a delay of 101 days: $0.96 \pm 0.04$, exact numbers see Table 1). However, this value was independent of storage time, and identical results were obtained for storage times of 2 and 78/101 days (Table 1) and therefore anomalous fading can be excluded for these samples. This is in agreement with a study from Molodkov et al. (2007), suggesting that at least part of the IRSL depletion is connected with tunnelling processes in the early stages of relaxation, and that the characteristic time of attenuation for these processes is several days, after which the tunnelling probability falls below a level that would result in a significant age underestimation.

Dose rates were calculated from $\mathrm{U}$, Th and $\mathrm{K}$ contents measured using high-resolution gamma spectrometry (Table 2). Note that the dose rate is calculated from sediment surrounding the IRSL sample. While for most samples there was a minimum of $30 \mathrm{~cm}$ radius sphere of homogenous sediment around the sampling position, 
Table 2 Dose rate data including $\mathrm{K}$, Th and $\mathrm{U}$ concentrations as measured by high-resolution gamma spectrometry
Note that a $10 \%$ uncertainty applies to the cosmic dose rate. Water content is assumed to be $3 \pm 3 \%$, based on measurements on the samples and comparison with related water content data from similar sites

\begin{tabular}{llrlrl}
\hline Sample & \multicolumn{1}{l}{$\begin{array}{l}\text { Dose } \\
\text { rate }(\mathrm{Gy} / \mathrm{ka})\end{array}$} & \multicolumn{1}{c}{$\begin{array}{l}\text { Cosmic dose } \\
\text { rate }(\mathrm{mGy} / \mathrm{ka})\end{array}$} & \multicolumn{1}{l}{$\mathrm{K}(\%)$} & \multicolumn{1}{l}{ Th $(\mathrm{ppm})$} & $\mathrm{U}(\mathrm{ppm})$ \\
\hline MAJ1 & $3.55 \pm 0.17$ & 8 & $1.94 \pm 0.02$ & $8.31 \pm 0.39$ & $2.19 \pm 0.12$ \\
MAJ2 & $2.50 \pm 0.09$ & 21 & $1.30 \pm 0.02$ & $5.34 \pm 0.45$ & $1.36 \pm 0.09$ \\
MAJ3 & $3.59 \pm 0.14$ & 197 & $1.99 \pm 0.02$ & $7.45 \pm 0.33$ & $1.62 \pm 0.07$ \\
MAJ4 & $3.07 \pm 0.11$ & 97 & $1.82 \pm 0.02$ & $6.73 \pm 0.22$ & $0.98 \pm 0.14$ \\
MAJ5 & $2.92 \pm 0.12$ & 27 & $1.79 \pm 0.02$ & $5.39 \pm 0.17$ & $1.18 \pm 0.01$ \\
MAJ6 & $3.09 \pm 0.11$ & 21 & $2.03 \pm 0.02$ & $6.15 \pm 0.42$ & $0.76 \pm 0.04$ \\
MAJ7 & $3.99 \pm 0.13$ & 181 & $2.13 \pm 0.02$ & $10.26 \pm 0.28$ & $1.61 \pm 0.09$ \\
MAJ8 & $3.24 \pm 0.10$ & 52 & $1.81 \pm 0.02$ & $8.85 \pm 0.18$ & $1.21 \pm 0.02$ \\
MAJ9 & $3.87 \pm 0.13$ & 32 & $2.06 \pm 0.02$ & $10.57 \pm 0.17$ & $2.24 \pm 0.07$ \\
MAJ10 & $4.10 \pm 0.13$ & 145 & $2.26 \pm 0.02$ & $9.28 \pm 0.07$ & $2.36 \pm 0.02$ \\
MAJ11 & $3.46 \pm 0.13$ & 197 & $1.85 \pm 0.02$ & $6.69 \pm 0.14$ & $1.91 \pm 0.13$ \\
MAJ12 & $3.02 \pm 0.39$ & 181 & $1.68 \pm 0.02$ & $4.98 \pm 0.45$ & $1.50 \pm 0.07$ \\
MAJ14 & $4.30 \pm 0.18$ & 15 & $2.34 \pm 0.02$ & $10.84 \pm 0.47$ & $2.74 \pm 0.26$ \\
MAJ15 & $3.09 \pm 0.13$ & 32 & $1.66 \pm 0.02$ & $7.16 \pm 0.47$ & $1.69 \pm 0.21$ \\
MAJ16 & $4.22 \pm 0.15$ & 153 & $2.30 \pm 0.02$ & $9.39 \pm 0.42$ & $2.54 \pm 0.13$ \\
MAJ17 & $3.98 \pm 0.14$ & 65 & $2.09 \pm 0.02$ & $9.55 \pm 0.41$ & $2.63 \pm 0.17$ \\
MAJ19 & $3.05 \pm 0.33$ & 197 & $1.65 \pm 0.02$ & $6.06 \pm 0.77$ & $1.34 \pm 0.74$ \\
MAJ20 & $3.33 \pm 0.38$ & 175 & $1.72 \pm 0.02$ & $7.84 \pm 0.46$ & $1.72 \pm 1.01$ \\
\hline
\end{tabular}

$\sim 10 \%$ of the sampling sites were from sand layers less than $30 \mathrm{~cm}$ thick. For these samples, the influence of the layers above and below the sampling site on the gamma dose rate were modelled using ADELE software (Kulig $2005)$ by varying the values for $U$, Th and $K$. Note that the values do not vary much as the thin sand sheets $(<30 \mathrm{~cm})$ were only sampled from sequences underlying fans that were sourced from catchments with uniform bedrock geology. From this modelling, it is concluded that dose rates for these particular samples vary by a maximum of $5 \%$ due to inhomogeneous gamma irradiation from surrounding layers. Based on the results from high-resolution gamma spectrometry, significant disequilibrium in the uranium decay series can also be excluded. Actual water content of the samples was measured using the weight difference before and after heating, and was close to 0 . Taking into account past periods of a wetter climate, the average water content was assumed to be $3 \pm 3 \%$.

\section{Results and interpretation}

Sedimentology of Quaternary deposits

\section{Terrace deposits}

The top of terrace deposits represent flat, planar surfaces. Terraces occur at two and in some locations three levels. The sedimentological architecture is characterized by an amalgamated stack of 2- to $4 \mathrm{~m}$-thick units of poorly sorted, clast-supported conglomerates with a coarse-grained sandy matrix. The clasts are subrounded and sometimes imbricated, but the sedimentary fabric is predominantly massive (Fig. 6a, f). The contacts between individual units are gradual. At the outcrop scale, erosional unconformities are rare (Fig. 6a). However, we cannot exclude that hiatuses or erosional unconformities are present at a larger scale, since observations of related features require large-scale, well accessible exposures, which is not the case here. This issue will become important when discussing the OSL ages of sites 12, 14 and 15 (Figs. 1, 7). Interbedded decimetre-thick units of medium- to coarse-grained sandstone sheets and lenses are seldom, and where they occur they are occasionally deformed, by the overlying sediment. Well-developed paleosoils with distinct pedogenetic stratifications and mottling are absent within terrace deposits. Clast counts of conglomerates reveal abundant magmatic constituents (quartz porphyry, basalt, ignimbrite and also granitic rocks) with a mixture of low-metamorphic sandstones and micritic limestones. Gravel bars in the modern riverbed have a similar petrographic composition with an overwhelming majority being either magmatic rocks or low-metamorphic sandstones.

The petrographic similarity between the modern and ancient river deposits suggests an identical sediment source. The poor sorting of the conglomerates indicates that the transport distance of the clasts within the trunk river was short, and that the depositional environment was of high energy. The massive fabric of the conglomerates and clast imbrication implies transport and deposition of 
Fig. 6 a Imbricated and massive bedded fluvial conglomerates that are moderately sorted and clast supported. b Modern analogue for braided river deposits with large longitudinal bars separating braided channels. c Section of fan that is made up by stacked hyperconcentrated flow deposits with sand interbeds and a matrixsupported debris flow unit at the base. d Sedimentary $\log$ of c. e Conglomerates (river deposits) at the base and breccia (fan deposits) at the top. $\mathbf{f}$ Location of sample site 1 (Fig. 1)
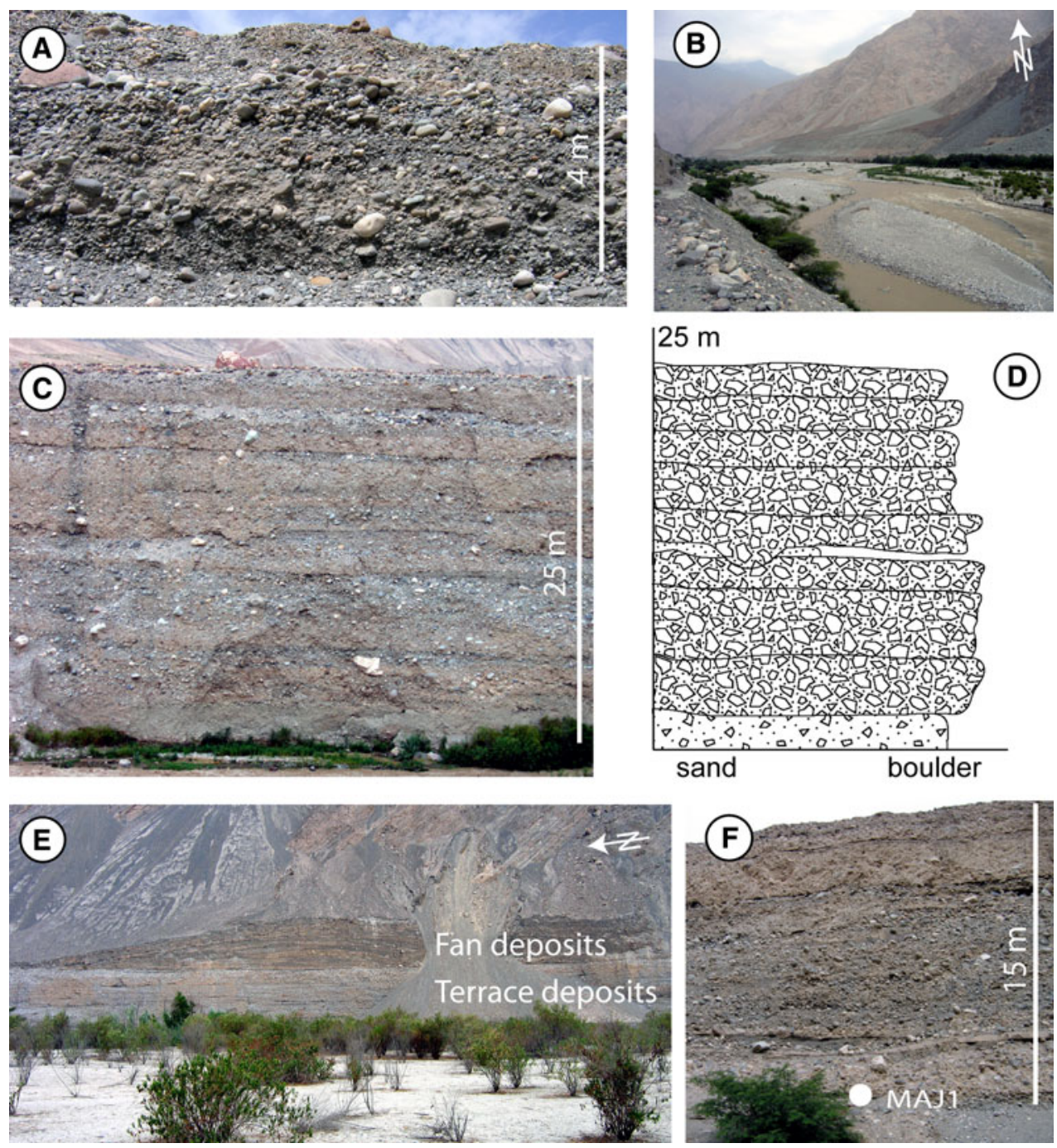

bedload by a braided river system during flood stages, as is the case at present (Fig. 6b). In such an environment, the finer-grained sediment was most probably deposited during waning floods on fluvial bar tops or on floodplains (Miall 1978). The absence of well-developed paleosoils together with a lack of erosional unconformities points towards near-continuous stacking of sediment without larger periods of stasis or truncation. However, as outlined above, the occurrence of a hiatus at larger scales cannot be excluded at the moment.

\section{Fan deposits}

In contrast to the terrace deposits where the surface is flat, fan deposits have a convex-up morphology (Figs. 6, 8). The petrofacies of the fans is monomict and reflects the petrology of the local bedrock, which, in turn, is indicative of a local source. Fan deposits occur either as simple bodies or are stacked on top of terrace deposits (Fig. 6e). In a vertical section, a shift from river deposits with a distal source to locally sourced fan deposits is often observed. The contact between distally and locally sourced sediments is planar sharp, but can also be erosive with scours several metres deep. Fan deposits are made up of individual beds with angular to subrounded, poorly sorted clasts (Fig. 6c, d). The clast sizes span the whole spectrum from granules to boulders with diameters up to $1-2 \mathrm{~m}$. The beds reveal a massive, clast- to matrix-supported fabric. Horizontal stratifications of planar, up to several centimetrethick units also occur. Similar to the terrace deposits, erosional unconformities within the fans as well as paleosoils are rare. Note that unconformities are only observed where tributaries debouch into the trunk river (Fig. 8). Most of the fans are incised several tens of metre deep, and incised reaches comprise a matrix-supported refill. Accordingly, we collected samples from the fan (e.g. sites 4,5 ) and refill deposits (site 3) (Fig. 7a).

The clast- to matrix-supported fabric implies deposition by high- and low-concentrated debris flows (Costa 1988). In contrast, parallel-stratified, clast-supported units were 
Fig. 7 a Long profile and sedimentary units along with the location of OSL sites, and $\mathbf{b}$ chronostratigraphic chart. See text for further explanations
A

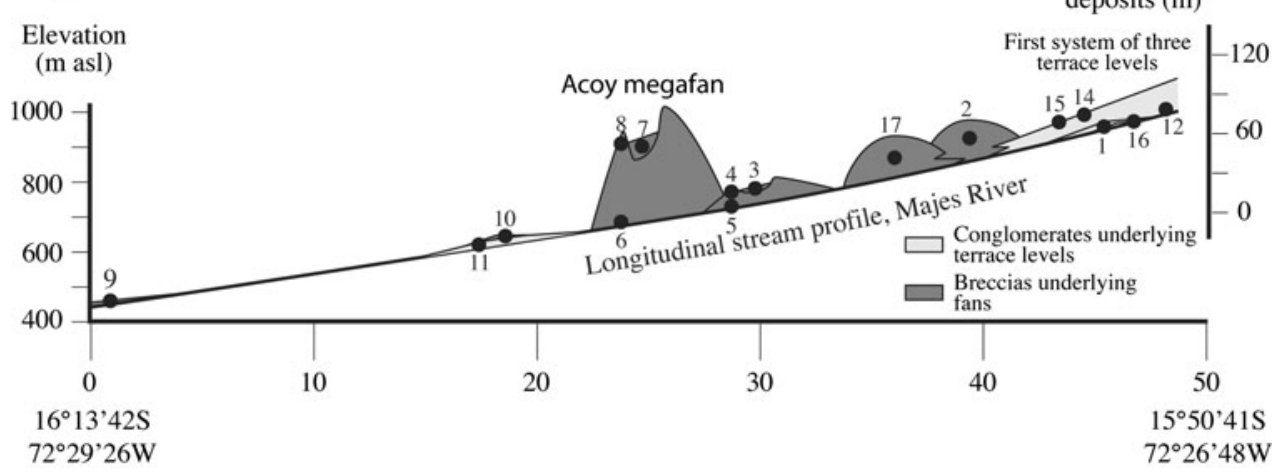

B

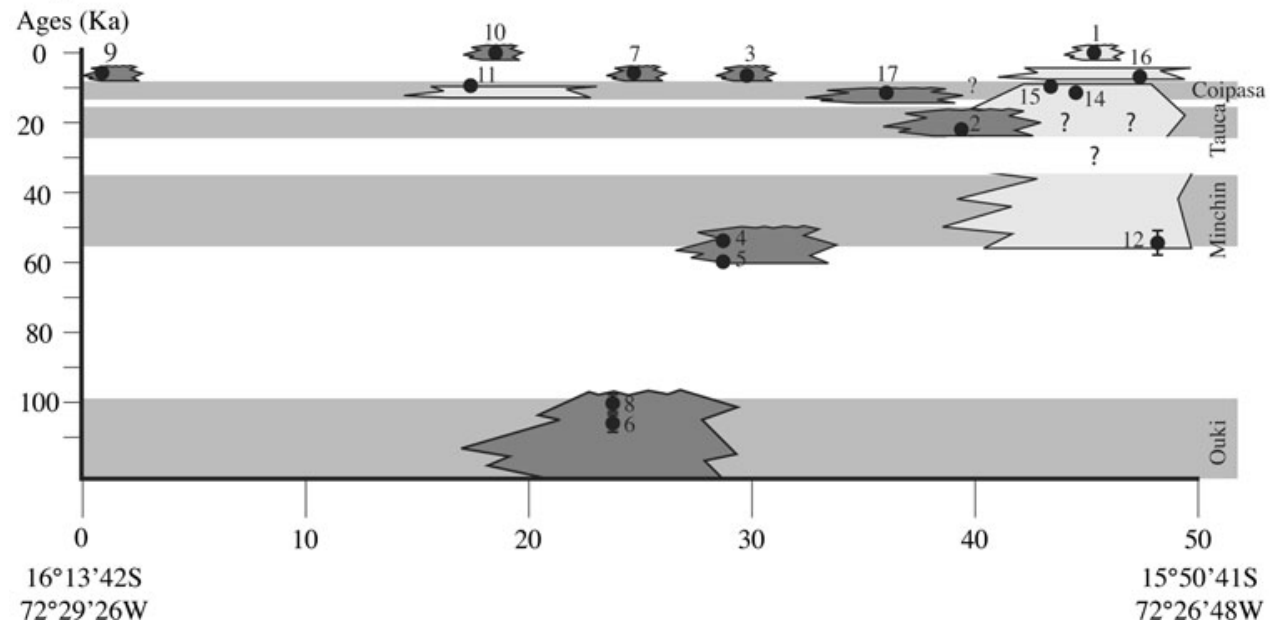

Fig. 8 Lower segment of the Majes valley with a typical telescope-like alluvial fan with a convex-up curvature. Note that this fan is currently dissected, and a lower-levelled fan accumulates at the mouth of the channel

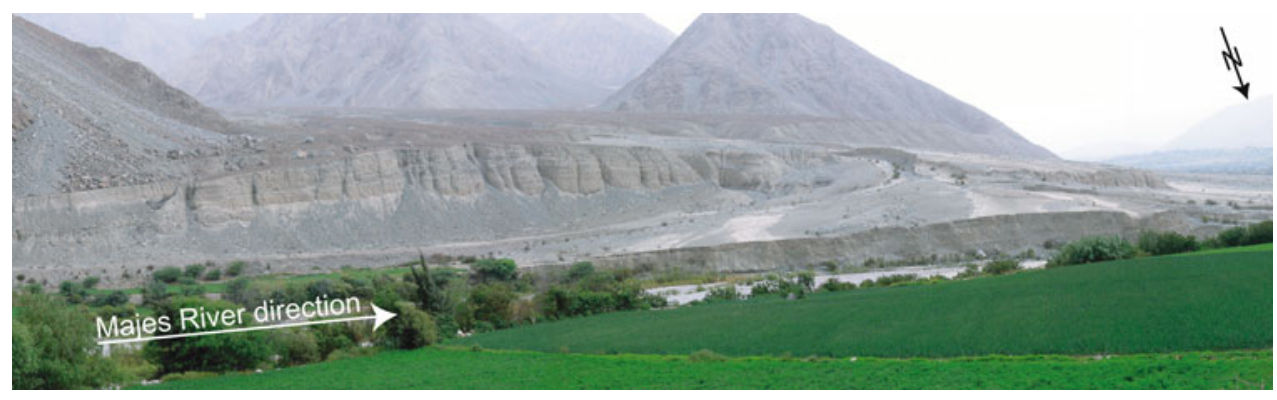

most likely deposited as sheet floods in the upper flow regime (Blair and McPherson 1994; Costa 1988). The absence of large erosional unconformities and paleosoils implies that stacking of sediment was not interrupted by periods of downcutting and erosion. The superposition of fan deposits on top of terrace units indicates progradation of the locally sourced fans into the main valley presumably because of in-excess sediment discharge from local sources (e.g. Schlunegger et al. 2009). In some places, telescopelike alluvial fans indicate individual pulses of sediment deposition (Fig. 8, Colombo 2005).

A prominent fan is located near the village of Acoy (Fig. 1). The size of the catchment measures about
$130 \mathrm{~km}^{2}$, and the size of the Acoy fan is about $20 \mathrm{~km}^{2}$. Inspection of satellite images revealed that the source area is located near the city of Chuquibamba (Figs. 1, 9a). There, the bedrock geology comprises Precambrian gneiss that is capped by the Huaylillas formation consisting of ignimbrite sheets that are dated 14-12 Ma (Thouret et al. 2007). The Huaylillas formation also forms the paleosurface ('pampa') that is clearly visible on satellite images (Fig. 9a). Also in the headwaters, the landscape is characterized by an amphitheatre-like structure with a diameter of about $10 \mathrm{~km}$ (Fig. 9a). The rim of the amphitheatre captures old streams from the 'Pampa' recording an older base level (e.g. Strasser and Schlunegger 2005 for a similar 

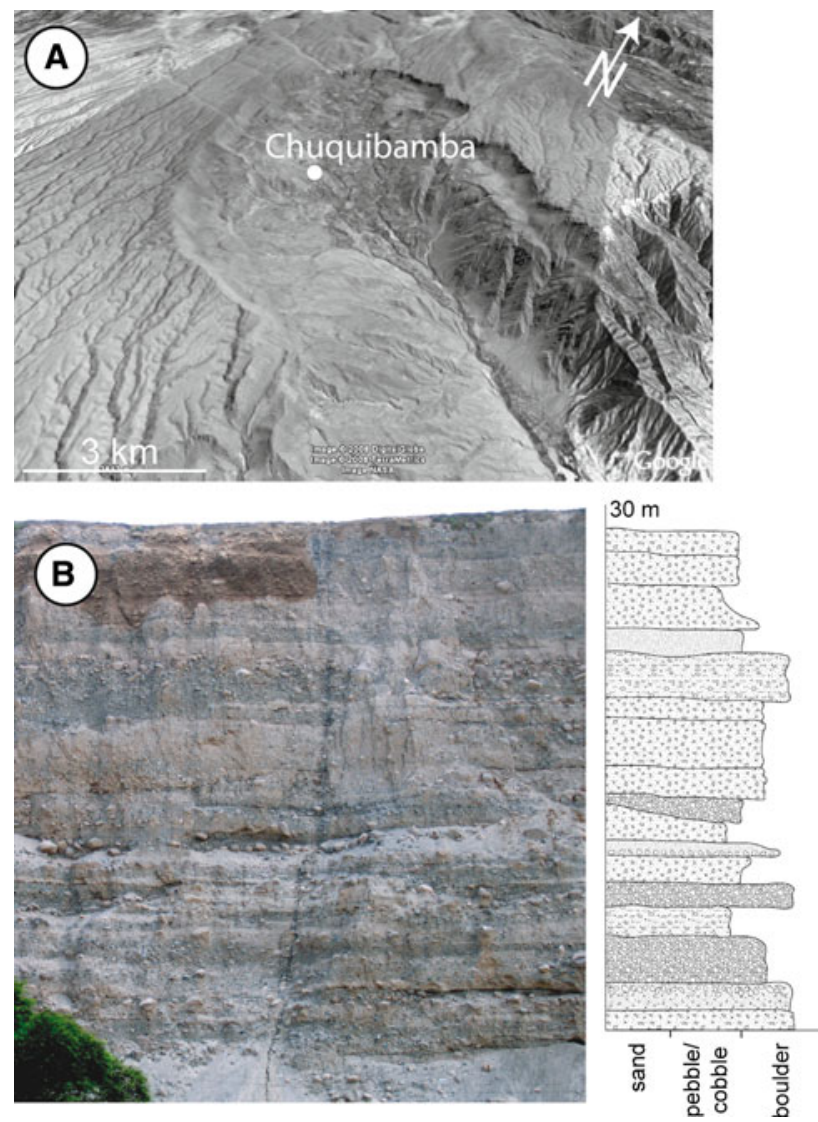

Fig. 9 a Google Earth ${ }^{\circledR}$ view of the catchment of the Acoy mega-fan with its amphitheatre-like form. Note that the scars cut an ancient drainage system. b Photograph illustrating the sedimentologic architecture and the corresponding log of the Acoy mega fan. See text for details

situation in northern Chile). The amphitheatre consists of two geomorphic units, an outer and thus higher, as well as an inner and lower part. The outer portion has a smooth topography. In some locations, landslide deposits can be inferred from the satellite images. The inner part has been dissected by the present drainage network, and the channelized processes have eroded headwards into the outer unit. The Acoy fan is located in the Majes valley at the confluence between the Majes River and the Chuquibamba tributary. The fan is made up of stacked debris flow and sheet flood units (Fig. 9b). Part of the sediment is of volcanic origin. Some sedimentary units have boulders at the base, and erosional unconformities are common. The thickness of the fan toe is about $100 \mathrm{~m}$ (Fig. 7a). At present, the Chuquibamba tributary channel is deeply incised into the fan deposits. Note that incised reaches host matrix-supported refills. Samples from the Acoy fan were collected from two sites (6 and 8), and the refill of incised reaches at site 7 (Fig. 7a).

Following the results of a detailed geomorphic study established on a similar location in northern Chile (Lluta valley; Hoke et al. 2004; Strasser and Schlunegger 2005), we interpret that the Acoy catchment records two phases of catchment development. During the first phase, the slopes along the present rim of the amphitheatre collapsed by landsliding. Similar to the situation at Lluta, we infer that landsliding was initiated by enhanced precipitation and a reduced basal shear stress due to an increasing hydrostatic pressure of the groundwater. Dissection and headward erosion in the inner, lower segment is considered here to be the response of the drainage network to a lowered base level. Fan construction might thus be the response to multiple phases of sediment production and surface erosion in the catchment, and it is at this stage difficult to relate the origin of the fan to a particular process. However, the predominance of sheet flood and debris flow deposits suggests a climate with high-intensity precipitation events.

\section{Talus deposits}

Talus deposits are particularly abundant in the lower part of the investigated reach. The deposits are made of centimetre- to decimetre-thick units of silt to coarse-grained sand that reveal a down-slope dip direction. The sand units are either massive bedded or parallel laminated and occasionally display decimetre-wide cross-beds. The top of the deposits is formed by a $5-10 \mathrm{~cm}$-thick salt crust, on top of which are scattered boulders (Fig. 10). Talus deposits were sampled at sites 19 and 20 .

The talus deposits most likely record transport of sediment by flash floods, either in the lower (cross-beds) or upper flow regimes (parallel lamination), and are most likely triggered by heavy rainfall. Interbedded units with a massive fabric might have been deposited by granular flows. Formation of the crust is attributed to evaporation of groundwater and subsequent precipitation of solute ions at the surface. The existence of this crust indicates the geomorphic stability of the slopes over a longer time period. Boulders on top of the salt layers either results from ongoing up-section sediment transport by evaporation and salt precipitation, or by winnowing of the fine fraction.

\section{Chronology of sediment aggradation}

The following results are based on IRSL dating of potassium-rich feldspars (Table 3) and radiocarbon dating of wood.

\section{Terrace deposits}

The first system of three terrace levels beneath the knickzone is located at the confluence between the Majes and the Capiza Rivers with distal sources (Fig. 1). Traces of the highest terrace level are found as sediment remnants 
Fig. 10 Sites of samples MAJ19 and MAJ20 in the lower part of the investigated reach. Samples were taken from talus deposits
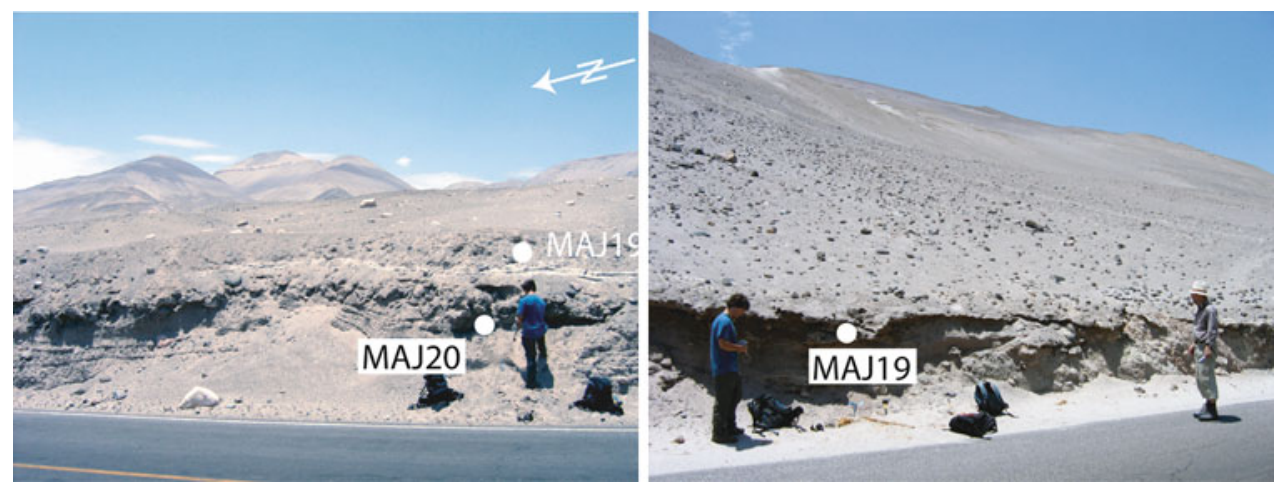

Table 3 Details of the IRSL samples including details on the paleodose statistics, dose rate and exact position of the samples

\begin{tabular}{|c|c|c|c|c|c|c|c|c|c|c|}
\hline \multirow[t]{2}{*}{ Sample } & \multirow{2}{*}{$\begin{array}{l}\text { Grain } \\
\text { size }\end{array}$} & \multirow[t]{2}{*}{$n^{\mathrm{a}}$} & \multirow{2}{*}{$\begin{array}{l}\sigma_{\mathrm{OD}} \\
(\%)^{\mathrm{b}}\end{array}$} & \multirow[t]{2}{*}{ Skew $^{c}$} & \multirow{2}{*}{$\begin{array}{l}\text { Dose rate } \\
(\mathrm{Gy} / \mathrm{ka})\end{array}$} & \multirow{2}{*}{$\begin{array}{l}\text { Prop. } \\
(\%)^{\mathrm{d}}\end{array}$} & \multicolumn{2}{|c|}{ Location $^{\mathrm{e}}$} & \multirow{2}{*}{$\begin{array}{l}\text { Altitude } \\
\text { (masl) }\end{array}$} & \multirow[t]{2}{*}{ Age (ka) } \\
\hline & & & & & & & Easting & Northing & & \\
\hline \multicolumn{11}{|l|}{ Terraces } \\
\hline MAJ1 & $100-150$ & 26 & 135.9 & 1.69 & $3.55 \pm 0.05$ & 22 & 773719 & 8245907 & 883 & $3.2 \pm 0.3$ \\
\hline MAJ16 & $104-149$ & 30 & 52.4 & 0.12 & $4.22 \pm 0.03$ & 13 & 774277 & 8246960 & 910 & $8.0 \pm 0.6$ \\
\hline MAJ11 & $104-149$ & 28 & 93.2 & 1.31 & $3.46 \pm 0.04$ & 18 & 769653 & 8228380 & 697 & $9.6 \pm 0.7$ \\
\hline MAJ15 & $104-149$ & 28 & 37.9 & 2.53 & $3.09 \pm 0.04$ & 79 & 773533 & 8247290 & 992 & $10.7 \pm 0.5$ \\
\hline MAJ14 & $104-149$ & 29 & 33.7 & 0.54 & $4.30 \pm 0.04$ & 15 & 774984 & 8246994 & 985 & $12.0 \pm 1.2$ \\
\hline MAJ12 & $104-149$ & 31 & 43.5 & 0.62 & $3.02 \pm 0.08$ & 19 & 775389 & 8246380 & 934 & $56.7 \pm 7.8$ \\
\hline \multicolumn{11}{|l|}{ Fans } \\
\hline MAJ10 & $100-150$ & 23 & 12.8 & 1.34 & $4.10 \pm 0.03$ & 86 & 769828 & 8227911 & 688 & $1.8 \pm 0.1$ \\
\hline MAJ7 & 149-208 & 27 & 82.0 & 1.35 & $3.99 \pm 0.03$ & 11 & 768683 & 8230888 & 791 & $7.9 \pm 0.6$ \\
\hline MAJ9 & $104-149$ & 28 & 29.0 & 3.33 & $3.87 \pm 0.03$ & 57 & 769088 & 8203852 & 541 & $6.4 \pm 0.4$ \\
\hline MAJ3 & $100-150$ & 23 & 115.9 & 1.09 & $3.59 \pm 0.04$ & 17 & 769182 & 8238086 & 1,051 & $8.5 \pm 0.7$ \\
\hline MAJ17 & $104-149$ & 30 & 31.1 & 2.10 & $3.98 \pm 0.04$ & 83 & 771412 & 8241350 & 832 & $12.9 \pm 0.6$ \\
\hline MAJ2 & $100-150$ & 30 & 12.6 & 1.28 & $2.50 \pm 0.03$ & 93 & 772545 & 8243788 & 930 & $23.0 \pm 1.0$ \\
\hline MAJ4 & $100-150$ & 28 & 45.5 & 0.61 & $3.07 \pm 0.03$ & 21 & 771408 & 8237395 & 828 & $51.2 \pm 3.4$ \\
\hline MAJ5 & $100-150$ & 31 & 37.0 & 0.45 & $2.92 \pm 0.04$ & 25 & 771431 & 8237045 & 804 & $59.7 \pm 3.6$ \\
\hline MAJ8 & $100-150$ & 26 & 28.0 & 1.12 & $3.24 \pm 0.03$ & 71 & 770509 & 8229898 & 769 & $101.6 \pm 4.9$ \\
\hline MAJ6 & $100-150$ & 30 & 24.1 & 1.23 & $3.09 \pm 0.03$ & 67 & 768865 & 8231062 & 819 & $107.0 \pm 5.0$ \\
\hline \multicolumn{11}{|l|}{ Talus } \\
\hline MAJ20 & $100-150$ & 31 & 31.9 & 1.91 & $3.33 \pm 0.11$ & 10 & 773737 & 8198215 & 530 & $41.2 \pm 5.9$ \\
\hline MAJ19 & $100-150$ & 29 & 27.5 & 0.66 & $3.05 \pm 0.11$ & 20 & 773202 & 8195943 & 662 & $61.1 \pm 8.7$ \\
\hline
\end{tabular}

${ }^{a}$ Number of measured aliquots

b Overdispersion

c Skew of the dose distribution

d Proportion of aliquots included in the FMM age

e Sample location in UTM 18S coordinates, datum: Provisional South American Datum 1956, except sample MAJ2 that is based on the WGS1984 datum

that are perched on hillslopes, and deposits can be followed farther downstream for several kilometres, after which they thin out. The height of the highest terrace level is approximately $30 \mathrm{~m}$ (Fig. 7a), and the top of this terrace has an age of $10.7 \pm 0.5 \mathrm{ka}$ (site 15). Similar ages were established for deposits at a comparable stratigraphic position (12.0 $\pm 1.2 \mathrm{ka}$, site 14), and for the top of a 3- to $4 \mathrm{~m}$-high terrace system approximately $25 \mathrm{~km}$ farther downstream (9.6 $\pm 0.7 \mathrm{ka}$, site 11, Fig. 7). Beneath the knickzone, the initiation of sediment aggradation was dated to $56.7 \pm 7.8 \mathrm{ka}$ (site 12 ) by a sample close to the present bedrock river bed. However, we do not know whether 
sediment accumulation was continuous until ca. $10 \mathrm{ka}$ (Fig. 7b). It may be possible that this terrace system represents an amalgamated stack of cut-and-fill systems with hiatuses or unconformities. Ages of lower-levelled terraces are $8 \mathrm{ka}$ (site 16), and $3.2 \mathrm{ka}$ (site 1, Fig. 7).

The time when sediment accumulation began coincides with the start of the Minchin paleolake cycle on the Altiplano (Fritz et al. 2004). The age of 12-10 ka assigned for the top of the terrace equals the time of the Coipasa paleolake cycle (Placzek et al. 2006). It is interesting to note that sediment accumulation and terrace formation starts at the confluence between Majes and Capiza Rivers. One explanation might be provided by the theory of fluid mechanics that indicate non-linear relationships between sediment transport capacity and water discharge (Tucker and Slingerland 1997). The effect of these particular relationships is largest at locations of flow convergence (e.g. Harvey 2007). Another reason for aggradation at that particular location is the observation that the valley begins to widen there. No climate-proxy data to explain the accumulation of younger terrace deposits are available. Nevertheless, we tentatively assign a climate control; note, however, that more detailed investigations are required to support this hypothesis.

\section{Fan and talus deposits}

Infrared stimulated luminescence ages reveal that fans in the Majes valley were formed during different time intervals in the Late Pleistocene and Holocene, with the oldest and largest fan being the Acoy mega-fan. An IRSL age from a sample of the lower half of the sequence, about $10 \mathrm{~m}$ above the present bedrock river bed, indicates that deposition of this fan predates $107.0 \pm 5.0 \mathrm{ka}$ (site 6, Fig. 7). A second sample taken at a stratigraphically higher position, about $3 \mathrm{~m}$ beneath the top of the fan (site 8), yields an age of $101.6 \pm 4.9 \mathrm{ka}$. Interestingly, this time interval is known to be a wet period on the Altiplano as inferred from the presence of the Ouki paleolake (Placzek et al. 2006). The second oldest fan was dated at $59.7 \pm 3.6 \mathrm{ka}$ (site 5) and $51.2 \pm 3.4 \mathrm{ka}$ (site 4) for samples taken from the base and the top of the fan. Similarly, the IRSL ages of the talus deposits are $61.1 \pm 8.7 \mathrm{ka}$ (site 19) and $41.2 \pm 5.9 \mathrm{ka}$ (site 20) (Figs. 1, 10). This is also a time period of enhanced precipitation on the Altiplano as inferred from the lacustrine deposits of the Minchin paleolake (Fritz et al. 2004; Chepstow-Lusty et al. 2005). Other fans formed at 25-20 ka (site 2, Tauca paleolake), around $12 \mathrm{ka}$ (site 17, Coipasa paleolake) and ca. $8 \mathrm{ka}$ (sites 3, 7, 9, Fig. 7b). One fan has an age of $1.8 \mathrm{ka}$ (site 10). Note that talus deposits younger than the Minchin time span were not identified in our study presumably because of incomplete sampling.
Two debris flow deposits on top of an incised channel on a fan were dated with the radiocarbon methodology that yielded an age of $\mathrm{AD} 1750 \pm 20$ (Lab-No B-9057 and B9058, uncalibrated $14 \mathrm{C}$ age $149 \pm 20$ and $154 \pm 21$ а вP). A similar radiocarbon age (AD 1727-1766) was also obtained from a debris flow deposit in the Pisco valley in southern Peru (Lab-No B-8779, uncalibrated radiocarbon age $147 \pm 21$ a вP) and for the lowest terrace system beneath the knickzone at Majes (site 1, Fig. 7). Interestingly, the time span from 1745 to 1752 is also listed in Ortlieb and Vargas (2003) as being a period of heavy rainfall and increased debris flow activity in the coastal regions of southern Peru.

\section{Discussion}

Controls on terrace and fan formation

Infrared-stimulated luminescence ages of terraces and fans in the Majes valley reveal that the major periods of aggradation span the time intervals between $\sim 110-100$, ca. $60-40$ and $12-8 \mathrm{ka}$ (Fig. $7 \mathrm{~b}$ ). These periods are known to be wet time intervals on the Altiplano with the formation of the Ouki, Minchin and Coipasa paleolakes (Fritz et al. 2004; Placzek et al. 2006). Note that fan deposits correlative with the Tauca sea-level highstand were also found in the Majes valley (Fig. 7b). Similar to the situation in the Pisco valley ca. $450 \mathrm{~km}$ farther north that hosts multiple cut-and-fill sequences (Steffen et al. 2009a), the correlation between sediment aggradation in the Majes trunk valley and wet periods on the Altiplano points towards a climatic forcing on the aggradation-degradation cycles. Enhanced precipitation in the headwaters and the middle segment resulted in increased erosion and transportation of sediment from the hillslopes into the channel network and towards the lower reaches. According to the results of conceptual models by Tucker and Slingerland (1997), we suggest that an imbalance between sediment supply from hillslopes, and sediment transport capacity of the receiving trunk stream, in combination with a decreasing river gradient and an increasing valley width beneath the knickzone most probably resulted in deposition of the sediment.

In contrast to the terrace deposits with sources on the Altiplano and in the reach of the knickzone, controls on sediment discharge in the tributary systems and mechanisms driving fan construction have to be local. Because of the absence of a vegetation cover, sediment discharge in the tributary drainage basins is very sensitive to changes in the rainfall pattern. At present, debris flow activity in the Peruvian coastal desert is observed if precipitation exceeds 20-30 $\mathrm{mm}$ in magnitude and $3 \mathrm{~h}$ in duration (Vargas et al. 2000). Accordingly, a change towards a climate with a 
higher frequency of high-magnitude precipitation events most likely initiated the construction of fans. This interpretation is in line with the results of the analyses of cutand-fill sequences in the Pisco valley where Steffen et al. (2009a) revealed that periods of sediment aggradation were contemporaneous with wet periods and lake-level highstands on the Altiplano. At Pisco, enhanced precipitation was considered to have resulted in the transfer of sediment from the hillslopes to the channel network, which in turn caused a higher than average supply of sediment to the trunk river. As a result, sediment started to accumulate on the valley floor. In addition, Steffen et al. (2009a) suggest that depletion of the regolith on the hillslopes decreased the supply of sediment to the trunk stream. As a result, the relative capacity of the trunk stream to entrain and transport sediment increased, which in turn caused the river to incise into the previously deposited sediment. We interpret that a similar mechanism initiated erosion in the Majes valley. Consequently, although that climate change may have initiated a phase of sediment accumulation, climatic forcing does not necessarily provide an explanation for the erosion following deposition of terrace and fan deposits. We are aware that the interpretation of a material-limited system requires the consideration of (1) lag times, (2) the time required to dismantle the regolith of a hillslope and (3) information regarding the length of humid phases, as these periods need to be sufficiently long to shift the sediment transport system into the autocyclic mode. We do not have the required quantitative information for point (1) and (2) at the moment and await the results of further investigations.

Although far more climate change cycles were registered in lake deposits on the Altiplano (e.g. Fritz et al. 2004, 2007; Placzek et al. 2006), only a few of these were recorded as terrace and fan systems in the Majes and Pisco valleys (Steffen et al. 2009a). A similar situation was also reported by Bull (1991) for the Mojave Desert and the San Gabriel Mountains in southern California. As outlined above, the transport mechanisms inferred from the terrace, fan and talus deposits all require water discharge either at local (fans and talus) or regional scales (terraces). However, Bull (1991) argued that supply of sediment and formation of terraces and fans not only depend on climate and water discharge, but also to a large extent on the availability of unconsolidated material on hillslopes. Bedrock weathering, therefore, has presumably been the most important limiting process for terrace and fan construction, especially in arid regions. This implies that the number of periods during which terraces and fans in the Majes valley were formed only provides a minimum estimate of climate cycles, and it is possible that more wet periods occurred that were not recorded in the sedimentary record because the time scales of climate change was presumably shorter than the response time of weathering and sediment production.

Regional paleoclimatic implications

The Minchin paleolake period between ca. 55 and $36 \mathrm{ka}$ (Chepstow-Lusty et al. 2005; Fritz et al. 2004) is characterized by sediment aggradation in a wide range of localities in the Central Andes. On the Altiplano close to Lake Titicaca, Farabaugh and Rigsby (2005) and Rigsby et al. (2003) linked sediment accumulation to wet time intervals, and erosion of previously deposited sediment to the arid period in between. Similarly, Trauth et al. (2003) correlated increased landslide activity in the northwestern Argentine Andes with increased precipitation during the Minchin paleolake cycle. In the Pisco valley, the dominant period of sediment aggradation occurred between 55 and $40 \mathrm{ka}$ (Steffen et al. 2009a), a time span that was also characterized by sediment deposition in the Majes valley. The analogies in the chronology of aggradation between the Majes and the Pisco catchments and the parallels between wet periods and sediment accumulation in other locations suggest that this wet period was not only restricted to local valleys, but affected a wide region of the Central Andes.

With reference to the period of the Minchin paleolake, there is also evidence for periods of increased precipitation on a regional scale during the terminal Pleistocene/Holocene transition $(\sim 12-8 \mathrm{ka})$. On the Altiplano, the Coipasa paleolake that is indicative of a wetter climate was dated at 13-11 ka (Placzek et al. 2006). Furthermore, the maximum glacial advance on the western Altiplano that was found to be summer precipitation-driven occurred between 14 and $10 \mathrm{ka}$ (Kull et al. 2008). Ortlieb and Vargas (2003) also suggest that the period between 13 and 9 ka was characterized by a much wetter climate with respect to the present day situation, based on the chronology of sediment deposition along the southern Peruvian coast. This is also evident in the data from Keefer et al. (2003) where the period of greatest debris flow activity was dated at 12-8.4 ka. Interestingly, such evidence was also found in archaeological data in the Quebrada (arroyo) Jaguay about $15 \mathrm{~km}$ north of Camaná where the Majes River debouches into the Pacific (Fig. 1). There, Sandweiss et al. (1998) and Sandweiss (2003) found indications for extended occupation by Paleoindian-age people during the terminal Pleistocene and the early Holocene, and suggested that water discharge in the Quebrada Jaguay was larger and more regular than at present. The headwaters of the Jaguay catchment reach as far as $100 \mathrm{~km}$ inland and have a maximum height of 4,700 masl close to the Nevado Coropuna. Therefore, its headwaters would have to be affected by the same climatic conditions as the reach of the Majes valley, where fans and terraces are present. 


\section{Conclusion}

The Late Pleistocene and Holocene evolution of the Majes valley was characterized by multiple stages of aggradation and erosion of sediment that resulted in the formation of distinct terrace and fan systems. The sedimentology of the terrace deposits indicates deposition by the Majes trunk river that has a distal source. IRSL dating correlates the time of terrace deposition with humid intervals on the Altiplano. In contrast, the fans were constructed by locally sourced tributary systems where sediment transport occurred by debris flows and sheet floods. Similar to the situation of the terrace deposits, fan construction was initiated by changes in climate and is attributed here to time periods with enhanced precipitation in the lower part of the catchment. Erosion of the previously deposited sediment is most likely the result of an autocyclic negative feedback such as depletion of the hillslope sediment reservoirs and the resulting increase of the relative capacity of the trunk stream to entrain and transport sediment. We propose at least three time intervals between $\sim 110-100, \sim 60-40$ and $12-8$ ka with enhanced precipitation in the Majes valley, with an additional period of sediment accumulation at ca. $20 \mathrm{ka}$. These periods are recognized as wet periods on the Altiplano with the formation of the Ouki, Minchin, Tauca and Coipasa paleolakes.

Acknowledgments We thank S. Lowick for improving the English of the manuscript. Radiocarbon dating was done by the Radiocarbon Laboratory at the Physics Institute of the University of Bern. Constructive review by $M$. Hinderer is greatly acknowledged. This research was supported by the Swiss National Science Foundation (Grant No. 20021-105188).

\section{References}

Arnold LJ, Bailey RM, Tucker GE (2007) Statistical treatment of fluvial dose distribution from southern Colorado arroyo deposits. Quat Geochronol 2:162-167

Auclair M, Lamothe M, Huot S (2003) Measurement of anomalous fading for feldspar IRSL using SAR. Radiat Meas 37:487-492

Baker PA, Seltzer GO, Fritz SC, Dunbar RB, Grove MJ, Cross SL, Tapia P, Rowe HD, Broda JP (2001a) The history of South American tropical precipitation for the past 25, 000 years. Science 291:640-643

Baker PA, Rigsby CA, Seltzer GO, Fritz SC, Lowenstein T, Bacher N, Veliz C (2001b) Tropical climate changes at millennial and orbital timescales on the Bolivian Altiplano. Nature 409:698701

Blair TC, McPherson JG (1994) Alluvial fan processes and forms. In: Abrahams AD, Parsons AJ (eds) Geomorphology of desert environments. Chapman \& Hall, London, pp 354-402

Blum MD, Törnqvist TE (2000) Fluvial responses to climate and sealevel change: a review and look forward. Sedimentology 47:248

Bull WB (1991) Geomorphic responses to climate change. Oxford University Press, London 326
Chepstow-Lusty A, Bush MB, Frogley MR, Baker PA, Fritz SC, Aronso $\mathrm{J}$ (2005) Vegetation and climate change on the Bolivian Altiplano between 108, 000 and 18, 000 yr ago. Quat Res 63:90-98

Colombo F (2005) Quaternary telescope-like alluvial fans, Andean Ranges, Argentina. In: Harvey AM, Mather AE, Stokes M (eds) Alluvial fans: geomorphology, sedimentology, dynamics, vol 251 (special publication). Geological Society, London, pp 69-84

Costa JE (1988) Rheologic, geomorphic, and sedimentologic differentiation of water floods, hyperconcentrated flows, and debris flows. In: Baker VR, Kochel RC, Patton PC (eds) Flood geomorphology. Wiley, New York, pp 113-122

Farabaugh RL, Rigsby CA (2005) Climatic influence on sedimentology and geomorphology of the Rio Ramis valley, Peru. J Sediment Res 75:12-28

Fontugne M, Usselmann R, Lavallée D, Julien M, Hatté C (1999) El Niño variability in the coastal desert of southern Peru during the mid-Holocene. Quat Res 52:171-179

Fritz SC, Baker PA, Lowenstein TK, Seltzer GO, Rigsby CA, Dwyer GS, Tapia PM, Arnold KK, Ku TL, Luo S (2004) Hydrologic variation during the last 170, 000 years in the southern hemisphere tropics of South America. Quat Res 61:95-104

Fritz SC, Baker PA, Seltzer GO, Ballantyne A, Tapia P, Cheng H, Edwards RL (2007) Quaternary glaciation and hydrologic variation in the South American tropics as reconstructed from the Lake Titicaca drilling project. Quat Res 68:410-420

Galbraith RF, Green PF (1990) Estimating the component ages in a finite mixture. Nucl Tracks Radiat Meas 17:197-206

Galbraith RF, Roberts RG, Laslett GM, Yoshida H, Olley JM (1999) Optical dating of single and multiple grains of quartz from Jinmium rock shelter, northern Australia: Part I. Experimental design and statistical models. Archaeometry 41:339-364

Garreaud R, Vuille M, Clement AC (2003) The climate of the Altiplano: observed current conditions and mechanisms of past changes. Palaeogeogr Palaeoclimatol Palaeoecol 194:5-22

Garzione CN, Hoke GD, Libarkin JC, Withers S, MacFadden B, Eiler J, Ghosh P, Mulch A (2008) Rise of the Andes. Science 320:1304-1307

Hampel A (2002) The migration history of the Nazca Ridge along the Peruvian active margin: a re-evaluation. Earth Planet Sci Lett 203:665-679

Harvey AM (2007) Geomorphic instability and change: introduction: implications of temporal and spatial scales. Geomorphology $84: 153-158$

Hoke GD, Isacks BL, Jordan TE, Yu JS (2004) Groundwater-sapping origin for the giant quebradas of northern Chile. Geology 32:605-608

Houston J, Hartley AJ (2003) The central Andean west-slope rainshadow and its potential contribution to the origin of hyperaridity in the Atacama Desert. Int J Climatol 23:1453-1464

Hsu JT (1992) Quaternary uplift of the Peruvian coast related to the subduction of the Nazca Ridge; 13.5 to 15.6 degrees south latitude. Quat Int 15-16:87-97

Keefer DK, Moseley ME, deFrance SD (2003) A 38 000-year record of floods and debris flows in the Ilo region of southern Peru and its relation to El Niño events and great earthquakes. Palaeogeogr Palaeoclimatol Palaeoecol 194:41-77

Korup O (2006) Rock-slope failure and the river long profile. Geology 34:45-48

Krbetschek MR, Götze J, Dietrich A, Trautmann T (1997) Spectral information from minerals relevant for luminescence dating. Radiat Meas 27:695-748

Kulig G (2005) Erstellung einer Auswertesoftware zur Altersbestimmung mittels Lumineszenzverfahren unter spezieller Berücksichtigung des Einflusses radioaktiver Ungleichgewichte in der 238U-Zerfallsreihe. Unpublished B.Sc. thesis, Technical University Bergakademie Freiberg 
Kull C, Imhof S, Grosjean M, Zech R, Veit H (2008) Late Pleistocene glaciation in the Central Andes: temperature versus humidity control: a case study from the eastern Bolivian Andes $\left(17^{\circ} \mathrm{S}\right)$ and regional synthesis. Glob Planet Change 60:148-164

Magilligan FJ, Goldstein PS (2001) El Niño floods and culture change: a late Holocene flood history for the Rio Moquegua, southern Peru. Geology 29:431-434

Magilligan FJ, Goldstein PS, Fisher GB, Bostick BC, Manners RB (2008) Late Quaternary hydroclimatology of a hyper-arid Andean watershed: climate change, floods, and hydrologic responses to the El Niño-Southern Oscillation in the Atacama Desert. Geomorphology 101:14-32

Mejdahl V (1985) Thermoluminescence dating of partially bleached sediments. Nucl Tracks Radiat Meas 10:711-715

Mettier R, Schlunegger F, Schneider H, Rieke-Zapp D, Schwab M (2009) Relationships between landscape morphology, climate and surface erosion in northern Peru at $5^{\circ} \mathrm{S}$ latitude. Int $\mathrm{J}$ Earth Sci 98:2009-2022

Miall AD (1978) Lithofacies types and vertical profile models in braided river deposits: a summary. In: Miall AD (ed) Fluvial sedimentology, vol 5. Canadian Society of Petroleum Geologists, Calgary, pp 597-605

Molodkov A, Jaek I, Vasilchenko V (2007) Anomalous fading of IRstimulated luminescence from feldspar minerals: some results of the study. Geochronometria 26:11-17

Murray AS, Wintle AG (2000) Luminescence dating of quartz using an improved single-aliquot regenerative-dose protocol. Radiat Meas 32:57-73

Ortlieb L, Vargas G (2003) Debris-flow deposits and El Niño impacts along the hyperarid southern Peru coast. In: Haas J, Dillon MO (eds) El Niño in Peru: biology and culture over 10,000 years. Fieldiana, Botany, vol 43. Field Museum of Natural History, Chicago, pp 24-51

Placzek C, Quade J, Patchett PJ (2006) Geochronology and stratigraphy of late Pleistocene lake cycles on the southern Bolivian Altiplano: implication for causes of tropical climate change. Geol Soc Am Bull 118:515-532

Rigsby CA, Baker PA, Aldenderfer MS (2003) Fluvial history of the Rio Ilave valley, Peru, and its relationship to climate and human history. Palaeogeogr Palaeoclimatol Palaeoecol 194:165-185

Robinson RAJ, Spencer JQG, Strecker MR, Richter A, Alonso RN (2005) Luminescence dating of alluvial fans in intramontane basins of NW Argentina. In: Harvey AM, Mather AE, Stokes M (eds) Alluvial fans: geomorphology, sedimentology, dynamics, vol 251 (special publication). Geological Society, London, pp $152-168$

Rodnight H, Duller GAT, Wintle AG, Tooth S (2006) Assessing the reproducibility and accuracy of optical dating of fluvial deposits. Quat Geochronol 1:109-120

Sandweiss DH (2003) Terminal Pleistocene through Mid-Holocene archaeological sites as paleoclimatic archives for the Peruvian coast. Palaeogeogr Palaeoclimatol Palaeoecol 194:23-40

Sandweiss DH, McInnis H, Burger RL, Cano A, Ojeda B, Paredes R, Sandweiss MC, Glascock MD (1998) Quebrada Jaguay: early South American maritime adaptations. Science 281:1830-1832

Schildgen TF, Hodges KV, Whipple KX, Reiners PW, Pringle MS (2007) Uplift of the western margin of the Andean plateau revealed from canyon incision history, southern Peru. Geology 35:523-526

Schlunegger F, Matter A, Mange M (1993) Alluvial fan sedimentation and structure of the southern Molasse Basin margin, Lake Thun area, Switzerland. Eclogae Geol Helv 86:717-750

Schlunegger F, Zeilinger G, Kounov A, Kober F, Hüsser B (2006) Scale of relief growth in the forearc of the Andes of Northern Chile (Arica latitude, $18^{\circ} \mathrm{S}$ ). Terra Nova 18:217-223
Schlunegger F, Badoux A, McArdell BW, Gwerder C, Schnydrig D, Rieke-Zapp D, Molnar P (2009) Limits of sediment transfer in an alpine debris-flow catchment, Illgraben, Switzerland. Quat Sci Rev 28:1097-1105

Spencer JQG, Robinson RAJ (2008) Dating intramontane alluvial deposits from NW Argentina using luminescence techniques: problems and potential. Geomorphology 93:144-155

Steffen D, Schlunegger F, Preusser F (2009a) Drainage basin response to climate change in the Pisco valley, Peru. Geology 37:491-494

Steffen D, Preusser F, Schlunegger F (2009b) OSL quartz age underestimation due to unstable signal components. Quat Geochronol 4:353-362

Strasser M, Schlunegger F (2005) Erosional processes, topographic length-scales and geomorphic evolution in arid climatic environments: the 'Lluta collapse', northern Chile. Int J Earth Sci 94:433-446

Tavera H, Fernández E, Bernal I, Antayhua Y, Agüero C, Rodríguez HSS, Vilcapoma L, Zamudio Y, Portugal D, Inza A, Carpio J, Ccallo F, Valdivia I (2006) The southern region of Peru earthquake of June 23rd, 2001. J Seismol 10:171-195

Thouret JC, Juvigne E, Mariño J, Moscol M, Legeley-Padovani A, Loutsch I, Davila J, Lamadon S, Rivera M (2002) Late Pleistocene and Holocene tephro-stratigraphy and chronology in southern Peru. Soc Geol Perú 93:45-61

Thouret JC, Wörner G, Gunnell Y, Singer B, Zhang X, Souriot T (2007) Geochronology and stratigraphic constraints on canyon incision and Miocene uplift of the Central Andes in Peru. Earth Planet Sci Lett 263:151-166

Trauth MH, Bookhagen B, Marwan N, Strecker MR (2003) Multiple landslide clusters record Quaternary climate changes in the northwestern Argentine Andes. Palaeogeogr Palaeoclimatol Palaeoecol 194:109-121

Tucker GE, Slingerland R (1997) Drainage basin response to climate change. Water Resour Res 33:2031-2047

Vargas G, Ortlieb L, Rutllant J (2000) Aluviones históricos en Antofagasta y su relación con eventos El Niño/Oscilación del Sur. Rev Geol Chile 27:157-176

Vargas G, Rutllant J, Ortlieb L (2006) ENSO tropical-extratropical climate teleconnections and mechanisms for Holocene debris flows along the hyperarid coast of western South America $\left(17^{\circ}-\right.$ $24^{\circ}$ ). Earth Planet Sci Lett 249:467-483

Vidal JC (1993) Geología de los cuadrángulos de Huambo y Orcopampa, vol 46. Instituto Geológico Minero y Metalúrgico, Lima

Wallinga J (2002) Optically stimulated luminescence dating of fluvial deposits: a review. Boreas 31:303-322

Wang X, Auler AS, Edwards RL, Cheng H, Cristalli PS, Smart PL, Richards DA, Shen CC (2004) Wet periods in northeastern Brazil over the past $210 \mathrm{kyr}$ linked to distant climate anomalies. Nature 432:740-743

Wells LE (1990) Holocene history of the El Niño phenomenon as recorded in flood sediments of northern coastal Peru. Geology 18:1134-1137

Wipf M, Zeilinger G, Seward D, Schlunegger F (2008) Focused subaerial erosion during ridge subduction: impact on the geomorphology in south-central Peru. Terra Nova 20:1-10

Woodman R (1998) El Fenómeno El Niño y el Clima en el Perú. In: El Perú en los Albores del Siglo XXI/2 (Ciclo de Conferencias 1997-1998). Ediciones del Congreso del Perú, Lima, pp 201-242 